\title{
LIMITES SUBJETIVOS DA EFICÁCIA DA SENTENÇA E DA COISA JULGADA NAS AÇÕES COLETIVAS
}

\author{
SUBJECTIVE LIMITS OF EFFECTIVENESS OF JUDGEMENTS IN COLLECTIVE LAW SUITS
}

José Rogério Cruz e Tucci ${ }^{1}$

\begin{abstract}
Resumo:
O ajuizamento de uma ação de aspecto coletivo implica evidente redução de custo e tempo, se comparados com aqueles que seriam despendidos em centenas de demandas individualmente aforadas para atingir idêntico escopo.

Palavras-chave: Tutela individual. Tutela coletiva. Direitos transindividuais. Direitos difusos. Direitos coletivos. Direitos individuais homogêneos. Coisa julgada.
\end{abstract}

\begin{abstract}
:
The filing of an action with collective reach aims to reduce costs and time, compared with the cases that would require hundreds of singular demands.

Keywords: Individual protection. Collective protection. Diffuses rights. Collective rights. Homogeneous individual rights. judgement which has become final.
\end{abstract}

1. Acesso à Justiça: da tutela individual à tutela coletiva

É de suma relevância que o processo civil também disponha de mecanismos aptos a realizar uma das funções institucionais que em época moderna lhe toca, qual seja a de assegurar, a um grupo de jurisdicionados que tenha razão, praticamente tudo aquilo e exatamente aquilo que, porventura, tenha direito de receber.

Não há dúvida de que o ajuizamento de uma ação de espectro coletivo implica evidente redução de custo e tempo, se comparados com aqueles que seriam despendidos em centenas de demandas individualmente aforadas para atingir idêntico escopo. Andrea Giussani informa que as estatísticas realizadas, em época relativamente recente, nas Cortes norte-americanas, revelam que, apesar de os procedimentos relativos a ações de grupo serem, em média, quatro vezes mais lentos do que aqueles de causas individuais, o resultado global atingido com as primeiras, considerando-se o trinômio custo-tempobeneficio, é extremamente compensador. Afirma, nesse sentido, que "a maioria da mais

\footnotetext{
Professor Titular de Direito Processual da Faculdade de Direito da Universidade de São Paulo. Ex-Presidente da Comissão de Pós-Graduação da Faculdade de Direito da Universidade de São Paulo. Assessor ad hoc da FAPESP. Ex-Presidente da AASP. Advogado em São Paulo.
} 
recente doutrina norte-american a converge para individuar uma das finalidades primárias das class actions na realização de objetivos de economia processual'. ${ }^{2}$

Ainda que os interessados pertençam à camada mais privilegiada da sociedade, a class action constitui praticamente o único caminho apto a permitir o acesso à justiça, quando o objeto da causa for relativamente pequeno em relação ao custo total do litígio, para justificar individual batalha: em várias circunstâncias, as despesas judiciais e outros gastos necessários para custear uma demanda de natureza individual podem extrapolar o valor do objeto do próprio litígio... ${ }^{3}$

No que concerne ao nosso sistema processual, é ponto pacífico que a tutela dos denominados direitos difusos e coletivos recebeu relevante tratamento legislativo, visando tornar o processo mais efetivo à parcela maior de jurisdicionados. Realmente, a despeito do perfil conservador da evolução da Ciência Processual brasileira, que sempre deu muita importância ao processo de conotação individual, é certo que a década de 80 foi marcada pelo grande avanço da legislação pátria no que se refere à tutela dos direitos coletivos. O nosso atual ordenamento tem, inclusive, servido de inspiração e modelo aos legisladores de países latino-americanos (como, por exemplo, a Argentina).

Além da ampla proteção à cidadania, inserida em inúmeros dispositivos da atual Constituição Federal, a legislação extravagante mais recente mostra-se deveras fecunda, possivelmente sem correspondência em outros ordenamentos, em relação à tutela daqueles direitos, mediante, e. g., o mandado de segurança coletivo, o mandado de injunção, o habeas data, as ações coletivas contempladas no Código de Defesa do Consumidor, a ação civil pública, a ação de improbidade administrativa e a ação para proteção dos investidores no mercado financeiro.

Com efeito, notável apresentou-se a inserção desses novos meios processuais fadados a tornar concretos os escopos sociais do processo, chegando a ponto de aguçar a atenção da doutrina alienígena. Morello, destacado jurista argentino, afirmou, há quase

2 GIUSSANI, Andréa. Studi sulle “class actions”. Padova: Cedam, 1996. p. 195-203.

3 Nos Estados Unidos, no precedente Herbst v. Able, ficou asseverado que: "A superioridade, em termos de economia processual, em se admitir estas ações (envolvendo alegadas violações a dispositivos da legislação securitária norte-americana) como class actions resulta óbvia. A economia aqui considerada não afeta apenas o tempo dos juízes e dos auxiliares da justiça, mas também o tempo das partes, particularmente dos demandados". O Juiz Robert Parker, do Texas, no julgamento do caso Cimino v. Raymark, declarou expressamente que: "se a Corte examina 30 processos por mês, demoraria 6 anos e meio para julgar os litígios abrangidos por esta class action e, ainda, restariam pendentes mais de 5.000 outros casos aguardando sentença..." (cf. FRIEDMAN, David. More Justice for Less Money. The Journal of Law and Economics, Chicago, v. 39, n. 1, p. 211-240, apr. 1996). É generalizada essa idéia de economia processual, fulcrada na equação tempo/benefício, em relação às ações coletivas (v., a respeito, HORNSTEIN, George D. Legal Therapeutics: the "Salvage" Factor. Harvard Law Review, Cambridge, v. 69, p. 665, n. 4, p. 658-682, feb. 1956; Comoglio, Il principio di economia processuale, v. 2, p. 312.; e, por último, ROMY, Isabelle. Litiges de masse. Des class actions aux solutions suisses dans les cas de pollutions et de toxiques. Fribourg: Éditions Universitaires, 1997. p. 168 ss). 
uma década, que nenhum estudioso do processo pode deixar de reconhecer a "notoria importancia del control de constitucionalidad, del reverdecimiento del amparo, de las nuevas expresiones del hábeas corpus, la acción amparista colectiva o el mandado de segurança colectivo, el hábeas data, consagrados estos últimos en la Constitución de Brasil de 1988". ${ }^{4}$

Inegável, outrossim, como tem revelado a experiência forense, que tais instrumentos, a serviço da proteção dos direitos supra-individuais, prestam-se para modificar a mentalidade formada a partir dos postulados emergentes do capitalismo, cumprindo, inclusive, uma função pedagógica em nossa sociedade. Ressalte-se, também, que a potencialidade das ações de conotação coletiva tem proporcionado aos cidadãos, cultural, técnica e economicamente mais fracos, um verdadeiro acesso aos tribunais, uma vez que, dada a condição de muitos lesados, dificilmente se disporiam a demandar individualmente. Induvidoso, pois, que todas essas vantagens só podem ser conquistadas se a utilização dos mencionados instrumentos for equacionada, com prudência, às suas reais finalidades, sob pena de inexorável descrédito e subversão da própria ordem jurídica.

Além dessa realidade, deve também ser reconhecido que, com a promulgação da Constituição Federal, era previsível que a idéia de cidadania fosse disseminada. Esse fato notório, resultante da aguda conscientização da titularidade de direitos de cidadão e de consumidor, implicaria - como implicou - um formidável aumento de litígios de conotação coletiva: cada vez mais a sociedade aflui aos tribunais para obter a satisfação de pretensões que, há pelo menos duas décadas, não se pensava serem tuteláveis (por exemplo: no âmbito da proteção do meio ambiente e dos direitos do consumidor).

O denominado processo de âmbito coletivo apresenta, assim, uma ruptura à barreira imposta pelo art. $6^{\circ}$ do Código de Processo Civil: aquela percepção herdada da Idade Média, coroada no Direito alemão, em que o processo era instituto entre partes (Sache der Partein), no qual o juiz, inerte, ficava observando o duelo judiciário entre os litigantes, com poderes instrutórios mínimos, limitando-se tão-somente a proferir uma sentença em consonância com o que havia ficado provado nos autos. Essa visão individualista que marcou o Direito Civil e o Direito Processual Civil no século XIX, obviamente, influenciou a legislação do século XX.

Suplantada essa concepção, pode-se alvitrar um processo com escopos sociais bem mais nítidos, um processo de conotação mais pública do que privada. Em nosso atual Direito Positivo, no contexto da denominada tutela jurisdicional da liberdade,

${ }_{4}$ MORELlO, Augusto M. Aspectos evidentes de la realidad. La reforma de la justicia. La Plata: LEP, 1998. p. 35. 
o micro sistema formado, em particular, pelas leis que regulamentam a ação popular (Lei n. 4.717/65), a ação civil pública (Lei n. 7.347/85), a ação de improbidade administrativa (Lei n. 8.429/92) e as ações para proteção dos consumidores (Lei n. 8.078/90) e dos investidores do mercado de capitais (Lei n. 7.913/89), têm regras próprias, que interagem com a legislação processual codificada, mantendo com essa estrito relacionamento no que se refere ao procedimento e às peculiaridades processuais.

\section{Conceituação dos direitos transindividuais}

Diante da legislação em vigor, não há dúvida de que o regime da coisa julgada, disciplinado no art. 103 do Código de Defesa do Consumidor, vale para todas as ações coletivas. ${ }^{5}$ Mesmo que não estejam envolvidas relações de consumo, por força do art. 21 da Lei n. 7.347/85, que recebeu nova redação pelo art. 117 do Código de Defesa do Consumidor, as normas processuais contempladas nesse diploma acabaram formando um sistema geral do processo das ações coletivas. Estas demandas, como é cediço, tendem a tutelar três diversificadas categorias de interesses ou direitos, em virtude da natureza da relação jurídica material: difusos, coletivos e individuais homogêneos.

Tal opção legislativa bem demonstra que a clássica dicotomia entre Direito Privado e Direito Público afigura-se irremediavelmente superada pela realidade social da época contemporânea, infinitamente mais complexa, mais articulada, mais sofisticada, impossível de ser emoldurada dentro daquela conhecida distinção. A nossa era põe em cena

\footnotetext{
Cf. GRINOVER, Ada Pellegrini. Código brasileiro de defesa do consumidor comentado pelos autores do anteprojeto. 6. ed. Rio de Janeiro: Forense, 1999. p. 813-814. Esclarece, ainda, a autora que: "Muito embora $\mathrm{o}$ art. 103 se refira às 'ações coletivas de que trata este Código', na realidade sua abrangência é maior. Com efeito, é certo que o veto presidencial recaiu sobre o art. 89 do Código, que determinava a aplicabilidade de todas as normas processuais a outros direitos ou interesses difusos, coletivos e individuais homogêneos. Mas é igualmente certo que permaneceu íntegro o art. 117 do Código, o qual acrescenta o novo art. 21 à Lei n. 7.347, de 24 de julho de 1985 - a denominada Lei de Ação Civil Pública -, determinando a aplicação, à defesa dos direitos e interesses difusos, coletivos e individuais, no que for cabível, dos dispositivos do Título III do Código do Consumidor. Ademais, é oportuno lembrar que o art. 110 do Código acrescentou o inc. IV ao art. $1^{\circ}$ da Lei n. 7.347, estendendo a abrangência desta a qualquer outro interesse difuso ou coletivo. Daí porque os dispositivos processuais do Código se aplicam, no que couber, a todas as ações em defesa de interesses difusos, coletivos, ou individuais homogêneos, coletivamente tratados... Assim, por exemplo, a coisa julgada na ação coletiva a que foi legitimado o sindicato, nos termos do art. $8^{\circ}$, inc. III, da CF, que ainda não encontrou assento próprio na legislação específica, deverá reger-se pelo estatuído no Cap. IV do Tít. III do Código. O mesmo ocorre com as ações promovidas por entidades associativas em defesa dos interesses coletivos de seus filiados (art. $5^{\circ}$, inc. XXI, da CF) e com as ações das comunidades e organizações indígenas em defesa dos interesses dos índios (art. 232 da CF). Pensamos que também o mandado de segurança coletivo, ainda dependente de tratamento legislativo próprio, reger-se-á, até eventual normação em contrário, pelos dispositivos do Código sobre a coisa julgada, que não colidem com a ordenação constitucional e legislativa, mas a complementam...". V., afirmando que o micro sistema do processo coletivo é igualmente aplicável ao mandado de segurança coletivo e à ação popular, ZAVASCKI, Teori Albino. Processo coletivo. São Paulo: Revista dos Tribunais, 1998. p. 191; ALVIM, Eduardo Arruda; MAZZEI, Rodrigo; NOLASCO, Rita Dias. Apontamentos sobre o processo das ações coletivas, processo civil coletivo. São Paulo: Quartier Latin, 2005. n. 6, p. 46; MANCUSO, Rodolfo Camargo. Ação popular. São Paulo: Revista dos Tribunais, 1993. p. 195 ss.
} 
novos interesses, novos direitos e deveres que, sem serem públicos, no sentido tradicional do vocábulo, são, no entanto, transindividuais: “destes ninguém é titular, ao mesmo tempo que todos, ou todos os membros de um determinado grupo, classe ou categoria, são seus titulares". 6

Pela circunstância de não terem delimitação pré-estabelecida, a respectiva formação dos direitos denominados transindividuais decorre necessariamente da constante evolução e mutação dos fenômenos sociais “de massa". Surgem os significativos conflitos empresariais, tecnológicos etc., aptos, no mundo globalizado, a projetar eficácia, a repercutir, de modo indiscriminado, sobre a esfera de direitos de grandes agrupamentos sociais e bens inerentes a todos, de forma indistinta, passíveis de fruição de modo quase que exclusivamente comum (ar, água como fonte de recursos da comunidade, informação pelos mass media...). ${ }^{7}$

A complexidade jurídica dos interesses supra ou metaindividuais que daí deriva, impôs precisa conceituação de suas variantes, visando propiciar, à luz da dogmática, correto entendimento aos operadores do Direito.

A solução mais abalizada foi a eleita pelo legislador pátrio, no art. 81 do Código de Defesa do Consumidor, ao conceituar o gênero - direitos transindividuais nas três referidas categorias (direitos difusos, direitos coletivos e direitos individuais homogêneos).

\subsection{Direitos difusos}

Os primeiros, ou seja, os direitos difusos, são os metaindividuais, de natureza indivisível, que têm como titulares pessoas indeterminadas, ligadas por circunstâncias meramente fáticas (art. 81, par. ún., I). Sem embargo de não haver um vínculo jurídico entre os respectivos sujeitos, os direitos difusos possuem a característica de serem indivisíveis. "Tomando como exemplo a tradicional referência às questões do meio ambiente para a compreensão da natureza e dimensão destes interesses, nota-se que o direito ao ar puro, à limpeza das águas, à higidez das florestas, à preservação das espécies animais são inerentes a toda a humanidade, ou, de forma mais específica, àquela comunidade que habita em determinada cidade, Estado, região ou país. Sua titularidade é de pessoas indeterminadas e indetermináveis, que não podem ser identificadas precisamente; são

${ }^{6}$ CAPPELLETTI, Mauro. Formazioni socialli e interessi di gruppo davanti alla giustizia civile. Rivista di Diritto Processuale, Padova, v. 30, n. 3, p. 361-402, 1975.

7 LEONEL, Ricardo de Barros. Manual do processo coletivo. São Paulo: Revista dos Tribunais, 2002. n. 3.3, p. 96. 
unidas por uma simples circunstância de fato ou contingencial extremamente mutável, o fato de residirem em determinado local ou região. O objeto do seu interesse é indivisível, pois não se pode repartir o proveito, e tampouco o prejuízo, visto que a lesão atinge a todos indiscriminadamente, assim como a preservação a todos aproveita; não há vínculo jurídico preciso entre os titulares". 8

\subsection{Direitos coletivos}

Já os direitos coletivos, que mereceram definição no art. 81, par. ún., inc. II, do Código de Defesa do Consumidor, ostentam igualmente natureza indivisível, cuja titularidade é de um grupo, categoria ou classe de pessoas ligadas entre si ou com a parte contrária por força de uma relação jurídica base. Essa relação jurídica unívoca que tem o condão de unir o conjunto de pessoas, em tal hipótese, preexiste à ameaça de lesão ou à própria lesão. Assim, por exemplo, numa demanda que tenha por escopo obter melhor condição de trabalho aos empregados de determinada indústria, jamais seria possível defender um em detrimento da defesa do direito de outro (aí está a marca da indivisibilidade). Todavia, esse direito coletivo difere do direito difuso, visto que limitado exclusivamente ao grupo determinado de trabalhadores da empresa demandada. A relação de emprego constitui, pois, a relação jurídica base.

Pedro Dinamarco, atendendo às exigências da didática, conjectura o seguinte exemplo: uma Corte de Justiça baixa portaria regulamentando o horário do expediente forense e, de forma ilegal, restringe o período de atendimento das serventias judiciais aos advogados. Viabiliza-se o ajuizamento de demanda, por meio de associação de classe, para o fim de, revogado o ato administrativo, beneficiar todos os advogados... ${ }^{9}$

Caracteriza-se, destarte, o direito coletivo: (i) por um mínimo de organização, para que seja possível a identificação dos membros do grupo; e (ii) por um vínculo jurídico subjacente, comum a todos os integrantes do grupo.

\footnotetext{
8 Id. Ibid., n. 3.4, p. 98-99.

9 MANCUSO, Rodolfo Camargo. op. cit., p. 56.
} 
2.3. Direitos individuais homogêneos

Por fim, os direitos individuais homogêneos são aqueles de origem comum (art. 81, par. ún., III, CDC). Apesar das críticas lançadas à definição legal, ${ }^{10}$ não subsiste dúvida de que os titulares de direito individual homogêneo podem legitimamente agir em juízo, em demandas atomizadas, em nome próprio, defendendo interesse também próprio. Todavia, o tratamento como categoria de direito transindividual decorre de opção legislativa, em prol da harmonia de julgamentos e, sobretudo, da economia processual.

Os direitos individuais homogêneos são aqueles que afetam mais de um sujeito em razão de uma gênese comum, cujo objeto é divisível. Normalmente, a coletividade de consumidores prejudicados pela aquisição de um mesmo produto defeituoso é que ostenta a titularidade de direito individual homogêneo.

\section{Disciplina legal}

Partindo exatamente das três categorias de direitos transindividuais, o já referido art. 103 do Código de Defesa do Consumidor traça as respectivas regras atinentes aos limites subjetivos da coisa julgada, a saber:

a) tratando-se de direitos difusos, a coisa julgada tem extensão erga omnes, exceto se o pedido for julgado improcedente com fundamento na insuficiência da prova, situação que possibilita a qualquer outro legitimado ajuizar nova ação, com idêntica causa de pedir, valendo-se de novo conjunto probatório;

b) tratando-se de direitos coletivos, a coisa julgada estende-se ultra partes (limitada ao grupo, categoria ou classe, cujos membros são unidos por uma mesma relação jurídica-base), excetuando-se igualmente a improcedência do pedido decorrente da insuficiência da prova; e

c) tratando-se de direitos individuais homogêneos, a coisa julgada tem expansão erga omnes, desde que o pedido seja julgado procedente, em benefício de todas as vítimas e seus sucessores.

Dispõe, ainda, o art. 16 da Lei n. 7.347/85, com a alteração introduzida pela Lei n. 9.494/97, que, na ação civil pública: “A sentença civil fará coisa julgada erga omnes, nos limites da competência territorial do órgão prolator, exceto se o pedido for

\footnotetext{
${ }^{10}$ V., e. g., PINHO, Humberto Dalla Bernardina de. A natureza jurídica do direito individual homogêneo e sua tutela pelo Ministério Público como forma de acesso à Justiça. Rio de Janeiro: Forense, 2002. p. 33; ARAÚJO FILHO, Luiz Paulo da Silva. Ações coletivas: a tutela jurisdicional dos direitos individuais homogêneos. Rio de Janeiro: Forense, 2000. p. 115.
} 
julgado improcedente por insuficiência de provas, hipótese em que qualquer legitimado poderá intentar outra ação com idêntico fundamento, valendo-se de nova prova".

Desse regime particularizado, duas observações se impõem: em primeiro lugar, em todas estas situações, a delimitação subjetiva do art. 472 do Código de Processo Civil mostra-se, em princípio, suficiente para atender às exigências das ações de conotação coletiva; e, ainda, a rejeição do pedido não acarretará qualquer prejuízo aos direitos individuais dos integrantes do grupo, categoria ou classe interessada, porque a coisa julgada se forma secundum eventum probationis.

\section{Terceiros nas ações coletivas e a coisa julgada secundum eventum probationis}

Tenha-se presente que a garantia do devido processo legal em relação aos terceiros na esfera do processo de Corte individual incide, igualmente, à evidência, nas demandas de espectro coletivo, nas quais, em regra, os titulares do direito material discutido não participam do processo.

Acerca da intrincada questão, anota Trocker que, nas controvérsias não estritamente individuais, em cujo núcleo há uma convergência por via de conexão ou dependência de interesses de grupo ou categoria, tornando impossível a presença no processo de todos os interessados, a garantia de defesa pode, igualmente, ser satisfeita sem que se cogite de qualquer violação aos direitos fundamentais do cidadão. Impõe-se, para tanto, o estabelecimento de um equilíbrio harmônico entre técnica de tutela substancial e garantia de defesa processual. ${ }^{11}$

Diante dessas duas exigências - técnica de tutela substancial e garantia de defesa processual - é de ser realçado o papel fundamental que indiretamente se atribuiu aos órgãos jurisdicionais no que concerne ao controle da atuação processual dos legitimados a demandar. Se importantes funções são reservadas ao juiz quanto à direção do processo individual, com certeza dilatam-se estas no âmbito da tutela coletiva, na qual, entre a inexorável extensão da coisa julgada a relações jurídicas conexas e a exigência de salvaguarda dos direitos dos litigantes estranhos ao processo, vem, certamente, valorizada a função judicial.

11 TROCKER, Nicolò. I limiti soggettivi del giudicato tra tecniche di tutela sostanziale e garanzie di difesa processuale. Rivista di Diritto Processuale, Padova, v. 43, p. 35-95, 1988, destacando, ainda, que: "a dupla exigência importa, de um lado, não excluir totalmente a eficácia ultra partes do julgado, e, de outro, tutelar os terceiros contra os danos que possam sofrer por força de uma sentença de cujo processo de formação não participaram, sem que isso amplie de modo ilimitado o rol de sujeitos que têm direito de ser ouvido em juízo. $\mathrm{E}$, por esse caminho, há uma harmônica coordenação entre técnica de tutela substancial e garantia de defesa processual, binômio esse que hoje é exigido, de modo sempre mais claro, pela mais autorizada doutrina e jurisprudência alemãs". 
O legislador nacional, em alguns pontos cruciais, com as sucessivas alterações que foram sendo introduzidas nos diversos textos legais, acabou assimilando o que de melhor, sob a vertente técnica, na esfera do processo coletivo, já havia sido colocado à prova, há muitos anos, nas experiências jurídicas que serviram de modelo ou, pelo menos, de fonte de inspiração para a redação da legislação brasileira, em particular, do Código de Defesa do Consumidor.

Quanto aos limites subjetivos da coisa julgada, o conceito unitário de consumidor traduz uma situação jurídica plurissubjetiva, na qual a relação substancial é única, mas intercorrente entre mais de um sujeito. A "afinidade" axiológica entre eficácia ultra partes e tutela dos interesses coletivos ou difusos baseia-se na relevância jurídica que a coisa julgada representa para a esfera dos direitos dos sujeitos estranhos ao processo, mas que são titulares da mesma res in iudicium deducta ou de um interesse qualificado por um vínculo de prejudicialidade-dependência. ${ }^{12}$

Ressalte-se, assim, que a legislação brasileira, em matéria de tutela coletiva, fez bem em rechaçar a formação da coisa julgada secundum eventum litis em relação a terceiros.

Embora o fenômeno da denominada coisa julgada secundum eventum litis tenha vigorado durante décadas na experiência jurídica das class actions norte-americanas, a partir da aludida reforma de 1966, nos Estados Unidos da América, cabe ao juiz concebido como o verdadeiro protagonista da ação de classe -, no início e durante todo o desenrolar do processo, examinar a performance da representação de todo o grupo.

Por outro lado, a produção da coisa julgada condicionada ao resultado do processo também tem sido muito criticada no Direito alemão, ${ }^{13}$ que, de certo modo, a contempla no $\S 21$ do $A G B-G e s e t z$, de 1976, o qual regulamenta as condições gerais do contrato. ${ }^{14}$ Entende-se, com efeito, que "a extensão ultra partes da eficácia apenas das sentenças de procedência implica alteração da Waffengleichheit der Partein (paridade

\footnotetext{
${ }^{12}$ V., no sentido do texto, PISANI, Andrea Proto. Note in tema di limiti soggettivi della sentenza civile. Foro Italiano, p. $2.385 \mathrm{ss}, 1985$.

13 V., opinando pela inconstitucionalidade da referida orientação, FISCH, William B. European Analogues to the Class Action: Group Action in France and Germany. The American Journal of Comparative Law, Berkeley, v. 27, n. 1, p. 51-79, winter 1979.

${ }^{14}$ Confira-se, sobre o tema, ROTH, Günter H. La nouvelle loi allemande sur les conditions générales du contrat (AGB-Gesetz) du 6.12.1976. Revue Internationale du Droit Comparé, Paris, p. 359, 1977; MICKLITZ, Hans W. La loi allemande relative au regime juridique des conditions générales des contrats du 9.12.76- bilan de onze annés d'application. Revue Internationale du Droit Comparé, v. 41, n. 1, p. 101-122, 1989.
} 
de armas das partes), ensejando inadmissível violação do princípio constitucional da isonomia". ${ }^{15}$

Na Itália, não-obstante ter granjeado alguns adeptos, é severa a crítica que Mauro Cappelletti lançou à denominada coisa julgada secundum eventum litis. De fato, se o autor é considerado parte idônea para defender os direitos de um grupo de consumidores, não parece razoável que se deva distinguir entre efeitos positivos e negativos, favoráveis ou desfavoráveis. É preciso ter presente que, também nas controvérsias respeitantes aos direitos coletivos e difusos, há sempre duas partes contrapostas. Se os efeitos favoráveis se estendem a terceiros e os desfavoráveis não, conclui-se que em relação à outra parte a solução secundum eventum litis opera somente em sentido negativo. Aflora, à toda evidência, que a produção industrial se consubstancia num bem social, uma vantagem coletiva, que não pode subordinar-se a um estado de insegurança jurídica, decorrente de injustificadas investidas judiciais. É bem de ver que, como sempre, também no caso da tutela dos interesses coletivos e difusos existem valores contrapostos, cada um deles, nos seus justos limites, dignos de respeito e proteção. Considerar somente a posição privilegiada de uma das partes - no caso, o consumidor -, e com isso colocar em risco a paridade de armas no processo, enseja uma forma ulterior de violação do devido processo legal e, ao mesmo tempo, uma simplificação de realidade extremamente complexa. ${ }^{16}$

Procurando manter um equilíbrio entre a posição jurídica das partes, à luz das garantias constitucionais do processo, o Projeto de Lei de Defesa do Consumidor da Argentina contém regra avançada, segundo a qual o atributo da imutabilidade do conteúdo decisório da sentença (para o consumidor) condiciona-se ao transcurso de um biênio, não mais podendo ser reavivada a questão após tal prazo (art. 23): “Sem prejuízo da subsistência das restantes ações que competem às partes, o processo de ação coletiva só poderá ser reaberto quando, dentro de um prazo improrrogável de dois anos a contar da intimação da sentença de improcedência, o legitimado ativo oferecer a produção de provas que tenham sido omitidas por motivos que não lhe são imputáveis". ${ }^{17}$

Foi, sem dúvida, nessa proposta legislativa, que, mais recentemente, os Autores do Código Modelo de Processos Coletivos para Ibero-América se inspiraram para

${ }^{15}$ Cf., reportando-se a manifestação do Bundesrat alemão, RAPIARDA, Cristina. Spunti in tema di efficacia del giudicato secundum eventum litis con particulare riguardo all'esperienza della legge tedesca sulle condizioni generali di contratto. In: Studi in Onore di Enrico Allorio. Milano: Giuffrè, 1989. v. 1, p. 777.

16 CAPPELLETTI, Mauro. Appunti sulla tutela giurisdizionale di interessi collettivi o diffusi, le azioni a tutela di interessi collettivi. Padova: Cedam, 1976. p. 205-206.

${ }^{17}$ Cf. apenso à obra de STIGLITZ, Gabriel A. Protección jurídica del consumidor. 2. ed. Buenos Aires: Depalma, 1990. p. 153-154. DINAMARCO, Pedro da Silva. Ação civil pública. São Paulo: Saraiva, 2001. n. 8.4.1, p. 107) entende que tal proposição legislativa desponta interessante e pode muito bem ser aproveitada pelo ordenamento jurídico brasileiro. 
a redação do $\S 1^{\circ}$ do art. 33: "Mesmo na hipótese de improcedência fundada nas provas produzidas, qualquer legitimado poderá intentar outra ação, com idêntico fundamento, no prazo de 2 (dois) anos, contados da descoberta de prova nova, superveniente, que não poderia ter sido produzida no processo, desde que idônea, por si só, para mudar seu resultado". ${ }^{18}$

O art. 103 do Código de Defesa do Consumidor, que dispõe sobre a dinâmica da coisa julgada nas ações coletivas, adotou o princípio clássico de que a imutabilidade do conteúdo da sentença vincula as partes e todos aqueles terceiros que se encontram substituídos no processo pelos legitimados legais. ${ }^{19}$

Em outras palavras, no processo coletivo, as coisas não se passam de modo muito diferente do que ocorre no processo individual, já que os limites subjetivos da coisa julgada adstringem as partes, seja no caso de acolhimento, seja no caso de rejeição, e impedem a propositura de outra ação coletiva que tenha idênticos pedido e causa de pedir, pelo mesmo ou por outro legitimado. ${ }^{20}$

E esse regime independe da natureza do direito questionado (difuso ou coletivo), desde que a improcedência do pedido não tenha se fundado na insuficiência de provas (art. 103, I e II). Na hipótese de direitos individuais homogêneos, a rejeição da demanda coletiva não impede o ajuizamento de ações individuais pelos interessados, quando nela não intervieram (art. 103, I e $\S 2^{\circ}$ ).

Acrescente-se, a propósito, que, segundo o enunciado do art. 94 do Código de Defesa do Consumidor, para eventual formação de litisconsórcio ativo ulterior, na ação referente a direitos individuais homogêneos, deve dar-se ciência aos interessados do ajuizamento da demanda por meio de edital, sem prejuízo da utilização, pelos órgãos de defesa do consumidor, de outros veículos de Comunicação Social. Contudo, a regra em apreço, a meu ver, constitui letra morta - e a prática confirma essa conclusão -, uma vez que, não intervindo no processo, o interessado, em caso de improcedência do pedido deduzido na demanda coletiva, poderá propor, em imediata seqüência, a ação para a defesa exclusiva de seu direito.

\footnotetext{
${ }_{18}$ Anote-se que essa mesma redação foi reproduzida no art. 12, $\S 5^{\circ}$, do Anteprojeto de Código Brasileiro de Processos Coletivos.

19 Preceitua o caput do art. 103 do CDC que: Nas ações coletivas de que trata este Código, a sentença fará coisa julgada:...". Vicente Greco Filho observa que o legislador incidiu aí em flagrante atecnia, pois confundiu a imutabilidade do conteúdo decisório da sentença com a extensão de seus efeitos a terceiros (GRECO FILHO, Vicente. Comentários ao Código de Proteção do Consumidor. São Paulo: Saraiva, 1991. p. 360-361).

${ }^{20}$ Em senso análogo: LUCON, Paulo; GABBAY, Daniela. Coisa julgada secundum eventum probationis $e$ pedido nas ações coletivas. São Paulo, 2006. texto inédito, p. 4.
} 
Nos moldes em que disciplinada a matéria, a formação da res iudicata dá-se secundum eventum probationis. Na hipótese de vitória do demandante, jamais se poderá voltar a discutir o que ficou definitivamente decidido. Todavia, se aquele legitimado ativo, que ajuizou a ação coletiva, conhecer resultado desfavorável, por insuficiência de provas, vale dizer, se a prova produzida pelo demandado determinar a rejeição do pedido, não há se falar em coisa julgada ultra partes, sendo possível, em qualquer momento posterior, o ajuizamento da demanda, por outro legitimado, com idêntico fundamento.

Assim, por exemplo, uma empresa é acionada por uma associação, que defende os interesses dos consumidores, e, diante das alegações deduzidas, requer a produção de prova pericial. Chega-se à conclusão, diante do material probatório colhido, de que o produto não se afigura defeituoso ou nocivo para o consumo. E, então, o respectivo pedido é julgado improcedente, com fundamento na insuficiência das provas produzidas pela associação. Ora, como a coisa julgada é secundum eventum probationis, o mesmo demandado pode ser novamente citado para responder aos termos de ação lastreada em idêntica causa petendi, mas em prova nova, movida pelo mesmo ou por outro legitimado.

É induvidoso que a opção feita pelo legislador, que constitui um meiotermo, supera em muito a técnica da coisa julgada secundum eventum litis. ${ }^{21}$

O regramento do art. 103 do Código de Defesa do Consumidor, em linhas gerais, não se diferencia daquele, já antigo, que disciplina a coisa julgada na ação popular (art. 18 da Lei n. $4.717 / 65) .{ }^{22}$

${ }^{21}$ Não-obstante, Botelho de Mesquita sustenta a inconstitucionalidade do tratamento afrontoso do princípio da isonomia processual dispensado à denominada ação coletiva para a defesa dos interesses individuais homogêneos, e anota que o ato decisório final que condenar o réu-fornecedor se torna imutável e indiscutível, "em benefício de todos que se pretenderem vítimas; mas a sentença que o absolver não lhe servirá para nada, podendo voltar a ser discutida por quem quer que seja. A autoridade do Poder Judiciário, neste caso, será nenhuma e a sentença não valerá o preço do papel em que tiver sido lançada. O direito de defesa do réu, por sua vez, ficará reduzido a uma fórmula inteiramente vazia, porque, por melhor que se defenda, nenhuma conseqüência prática daí decorrerá, a não ser a vitória isolada sobre a 'vítima' incauta que, ignorante, tenha optado por participar do processo em lugar de ficar de fora aguardando o resultado"!... (MESQUITA, José Ignácio Botelho de. Na ação do consumidor, pode ser inútil a defesa do fornecedor. Revista do Advogado, São Paulo, n. 33, p. 802, dez. 1990). Comunga com essa opinião, Mafra Leal, ao ponderar que o regime da coisa julgada no processo coletivo brasileiro é contraditório, no sentido de que o "representante adequado" (o legitimado a ajuizar a demanda) "só é considerado adequado quando a ação é benéfica... para se permitir a propositura da ação coletiva, faz-se um libelo contra o processo individual, com argumentos do movimento de acesso à Justiça e pregando-se a necessidade de se superarem as barreiras tradicionais impostas pela cláusula do devido processo legal, com o princípio do contraditório incluído. Quando se percebe que o pedido na ação coletiva pode ser improcedente, recorre-se aos mesmos argumentos que no primeiro momento rechaçaram: os princípios do processo civil clássico (contraditório, ampla defesa etc.)" (LEAL, Márcio Flávio Mafra. Ações coletivas: história, teoria e prática. Porto Alegre: Sérgio Fabris, 1998. p. 209).

${ }^{22}$ Há mais de dez anos, enfocando esse mesmo tema, manifestei-me contrário à sistemática acolhida no CDC quanto aos limites subjetivos da coisa julgada, imaginando que o legislador tivesse adotado, tout court, a 
Afastando-se dessa opinião, assinala, a respeito, Botelho de Mesquita, que, na ação popular, cujo pedido foi julgado improcedente, “a limitação da coisa julgada entre as partes não faz exceção à regra geral, nem contém qualquer ofensa à Constituição. É da regra geral que qualquer outro cidadão, diante de tal eventualidade, pudesse propor, depois, a sua ação popular. O que é excepcional é que este poder fique limitado ao caso em que a improcedência da ação tenha sido conseqüencia da insuficiência de provas. Acresce notar que a improcedência da ação popular por deficiência de provas contém, em geral, um juízo favorável ao autor a respeito da nulidade do ato, faltando apenas a prova da sua lesividade. É juizo que não dá inteira razão ao réu; ao contrário contém em si mesmo uma reprovação do ato. Já, no caso da ação do consumidor julgada improcedente (e não apenas por deficiência de provas, mas também por ficar cabalmente demonstrado que o réu está, com toda a razão, no exercício de um direito reconhecido) a situação é exatamente a oposta: a sentença declara que a pretensão do autor não tem fundamento nenhum. É caso, pois, em que a analogia cede diante do argumento a contrário". ${ }^{23}$

Por outro lado, é importante ressaltar que, no âmbito das ações coletivas, torna-se relevante a verificação, pelos juízes, durante toda a tramitação do processo, do comportamento processual do legitimado, que "representa" todo o grupo, visto que a trama entre os litigantes acarreta gravíssima ofensa às garantias do devido processo legal, que inclusive protegem os terceiros. Não é preciso destacar que o papel reservado aos órgãos jurisdicionais pelas legislações processuais modernas (incluindo a nossa) sempre foi o de um juiz ativo, cabendo-lhe, entre outras relevantes incumbências, velar pela conduta processual dos litigantes, prevenindo ou reprimindo qualquer ato atentatório à dignidade da justiça. ${ }^{24}$

Ademais, nos processos coletivos nos quais não atua como demandante, o Ministério Público integra o processo como fiscal da lei, devendo, em qualquer momento processual, noticiar ao juiz a suspeita da existência de conluio entre as partes.

técnica da coisa julgada secundum eventum litis (TUCCI, José Rogério Cruz e. Técnica processual civil no Código de Defesa do Consumidor, Devido processo legal e tutela jurisdicional. São Paulo: Revista dos Tribunais, 1993. n. 6, p. 119-120).

${ }^{23}$ MESQUITA, José Ignácio Botelho de. Na ação do consumidor, pode ser inútil a defesa do fornecedor. Revista do Advogado, São Paulo, n. 33, p. 802, dez. 1990.

${ }^{24}$ Cf., e. g., art. 125 do CPC. V., sobre esse importante aspecto, MOREIRA, José Carlos Barbosa. Os poderes do juiz na direção e na instrução do processo. Temas de direito processual. 4. série. São Paulo: Saraiva, 1989. p. 45 ss.; BEDAQUE, José Roberto dos Santos. Poderes instrutórios do juiz. 3. ed. São Paulo: Revista dos Tribunais, 2001. passim. 
5. Exame sistemático e crítico da técnica legal: posição de Botelho de Mesquita

Ao detectar as dificuldades para um tratamento sistemático da coisa julgada no Código de Defesa do Consumidor, Botelho de Mesquita inicia o seu estudo, dedicado a esse tema, afirmando que a expressão erga omnes, na redação do art. 103, inc. I, do Código de Defesa do Consumidor, possui um alcance bem mais limitado do que se supõe. Para tanto, o ilustre processualista paulista entende que "terceiros" são apenas os outros legitimados concorrentes, contemplados no art. 82.

Com efeito, escreve Botelho de Mesquita que os "terceiros que poderiam ser beneficiados ou prejudicados pela conclusão da sentença dada entre as partes são apenas os demais legitimados... Outras pessoas, como por exemplo quaisquer dos membros da coletividade titular do direito em causa, nunca poderiam pretender discutir ou modificar a sentença dada entre as partes, porque não têm legitimidade para tanto". ${ }^{25}$

Ademais, observa que se, de um lado, a lei é absolutamente ociosa ao estabelecer que a coisa julgada produz-se ultra partes no caso de procedência; de outro, a extensão da coisa julgada aos terceiros, improcedente se o pedido por outros motivos que não a insuficiência de provas, importa restrição que não ocorreria no sistema da legislação codificada. Consoante a disciplina do Código de Processo Civil, rejeitado o pedido de uma das ações concorrentes, a sentença só se tornaria imutável e indiscutível entre as partes, jamais para quaisquer terceiros, que conservariam incólumes as respectivas ações. ${ }^{26}$

No que concerne às ações previstas no art. 103, inc. II, do Código de Defesa do Consumidor, referentes aos direitos coletivos, a sentença faz coisa julgada ultra partes, circunscrita ao grupo, categoria ou classe, salvo a improcedência do pedido por insuficiência de prova. Nesse caso, a exemplo da hipótese anterior, qualquer legitimado poderá aforar outra ação, com idêntico fundamento.

A expressão ultra partes é utilizada no citado dispositivo como sinônima de erga omnes. Partindo do mesmo raciocínio, assevera Botelho de Mesquita que, "além das demais entidades concorrentemente legitimadas, não há ninguém que tenha legitimação para discutir ou pretender modificar a conclusão da sentença dada entre as partes numa ação fundada em interesse ou direito coletivo". E, igualmente, nessa situação, no que toca à improcedência do pedido não fundada em carência de elementos probatórios, o Código

\footnotetext{
${ }^{25}$ MESQUITA, José Ignácio Botelho de. A coisa julgada no Código do Consumidor, Coisa julgada. Rio de Janeiro: Forense, 2004. p. 35-36; Forense, Rio de Janeiro, v. 326, p. 82, 1994.

${ }^{26}$ Cf. Id. Ibid., p. 35-36; Id. Ibid., p. 82.
} 
do Consumidor é mais restritivo do que o tradicional sistema do Código de Processo Civil. $^{27}$

A ressalva contida no $\S 1^{\circ}$ do art. 103, no sentido de que a coisa julgada não prejudicará os direitos individuais dos integrantes da coletividade, irrompe totalmente desnecessária, porque, como é curial, a conclusão de qualquer sentença só se torna imutável e indiscutível em relação ao pedido, identificado pelo objeto e pela causa de pedir. As ações fundadas em direito individual terão sempre objeto e causa petendi distintos dos das demandas coletivas. Jamais poderiam ser por elas prejudicadas!

Por fim, em relação às ações coletivas fundadas em direitos individuais homogêneos, a teor do art. 103, inc. III, do Código de Defesa do Consumidor, a sentença fará coisa julgada erga omnes apenas no caso de procedência do pedido, para beneficiar todas as vítimas e seus sucessores.

Pondera, a propósito, Botelho de Mesquita, que se improcedente o pedido, a sentença será imutável e indiscutível apenas para as partes, como já decorre do regime do Código de Processo Civil. Se, pelo contrário, o pedido for acolhido estará inteiramente satisfeito o escopo das ações concorrentes de todos os legitimados, nada importando que a sentença se torne indiscutível ou-não; "não haverá mais ação alguma, com o mesmo objeto, a ser proposta". No mesmo sentido, afigura-se desnecessária a regra do $\S 2^{\circ}$ do art. 103, uma vez que, improcedente o pedido, o réu não está obrigado a indenizar. "Esta conclusão, por força do trânsito da sentença em julgado, tornar-se-á imutável e indiscutível perante as partes, mas não prejudicará terceiros. Logo, prejudicará as ações 'individuais' dos que foram partes no processo, mas não prejudicará as dos que dele não participaram. Tudo isto, porém, conforme já decorreria da aplicação do sistema do Código de Processo Civil’. ${ }^{28}$

Diante dessa análise técnica, cotejada com as normas que já regravam os limites subjetivos da coisa julgada nos processos de cunho individual, conclui Botelho de Mesquita que a legislação protetiva do consumidor "disse muito e criou muito pouco: o pouco que criou restringiu o sistema vigente em prejuízo dos titulares de direitos difusos ou coletivos". $\left.{ }^{29}\right]$

\footnotetext{
${ }^{27}$ Id. Ibid., p. 36-37; Id. Ibid., p. 83.

${ }^{28}$ MESQUITA, José Ignácio Botelho de. A coisa julgada no Código do Consumidor, Coisa julgada. Rio de Janeiro: Forense, 2004. p. 35-36;__. A coisa julgada no Código do Consumidor, Coisa julgada. Revista Forense, Rio de Janeiro, v. 326, p. 82, 1994. V., a propósito da natureza jurídica da intervenção individual na ação coletiva, Elton Venturi, Sobre a intervenção individual nas ações coletivas, Aspectos polêmicos e atuais sobre os terceiros no processo civil e assuntos afins (obra coletiva), p. 247 ss.

${ }^{29}$ Id. Ibid., p. 42; Id. Ibid., p. 84.
} 
6. Terceiros beneficiados pela coisa julgada

A despeito da coerente leitura sugerida por Botelho de Mesquita do aludido texto legal, a orientação que tem prevalecido, nessa matéria, é a que identifica os terceiros não nos co-legitimados dos arts. $5^{\circ}$ da Lei de Ação Civil Pública e 82 do Código de Defesa do Consumidor, mas, sim, nos sujeitos da situação de direito material. Desse modo, na posição de substituídos pelos entes legitimados, quando procedente o pedido, são eles diretamente beneficiados pela coisa julgada.

A lei especial impôs que, nas ações de corte coletivo, a imutabilidade do decisum, ao invés de ficar restrita às partes formais que participam do processo, conforme o caso, estende-se ultra partes. Assim, por exemplo, na procedência do pedido nas ações civis públicas ou coletivas, a imutabilidade deverá estender-se a todo o grupo, categoria ou classe de lesados, os quais não estão representados nos autos, mas substituídos pelos legitimados extraordinários autorizados por texto legal expresso. ${ }^{30}$

Como já observado, no processo coletivo, excetuando a já aludida coisa julgada secundum eventum probationis, o regime não é diferente daquele que incide no âmbito da tutela individual: os efeitos da sentença e a extensão da coisa julgada produzemse normalmente, seja na hipótese de acolhimento da pretensão, seja na de rejeição, e obstam à propositura de outra ação coletiva que tenha idênticos elementos objetivos (causa petendi e petitum).

7. Direitos individuais homogêneos: eficácia da sentença e extensão da coisa julgada

Como já enfatizado, tratando-se de direitos difusos e coletivos, o regime da coisa julgada, consagrado no art. 103, incs. I e II, é o da eficácia erga omnes, na medida em que, pela natureza indivisível daqueles, o julgamento deve ser uniforme para todos os interessados.

Diferente, como já observado, é a técnica aplicada aos direitos individuais homogêneos, que são, na essência, divisíveis. Dispõe o art. 103 do Código de Defesa do Consumidor que: "Nas ações coletivas de que trata este Código, a sentença fará coisa

\footnotetext{
${ }^{30}$ V., nesse sentido, MAZZILLI, Hugo Nigro Notas sobre a mitigação da coisa julgada no processo coletivo. In: MAZZIE, Rodrigo; NOLASCO, Rita Dias (Coord.). Processo civil coletivo. São Paulo: Quatier Latin, 2005. p. 326. Cf., ainda, sob o prisma da constitucionalidade da regra que governa os limites subjetivos nas ações coletivas, GUERRA FILHO, Willis Santiago. Eficácia ultra-subjetiva da coisa julgada e garantia do contraditório em ações coletivas. In: MAZZEI, Rodrigo; NOLASCO, Rita Dias (Coord.). Processo civil coletivo. São Paulo: Quatier Latin, 2005. p. 320 ss; GRINOVER, Ada Pelegrini. As garantias constitucionais do processo nas ações coletivas. Revista de Processo, São Paulo, v. 11, n. 43, p. 19-30, jul./set. 1986, n. 9, p. 23. Confira-se, na literatura estrangeira, CARPI, Federico. Cenni sulla tutela degli interessi collettivi nel processo civile e cosa giudicata. Rivista Trimestrale di Diritto e Procedura Civile, p. 960-961, 1974.
} 
julgada:... III - erga omnes, apenas no caso de procedência do pedido, para beneficiar as vítimas e seus sucessores, na hipótese do inciso III do parágrafo único do art. 81 [direitos individuais homogêneos]... $§ 2^{\circ} \mathrm{Na}$ hipótese prevista no inciso III, em caso de improcedência do pedido, os interessados que não tiverem intervindo no processo como litisconsortes poderão propor ação de indenização a título individual".

Extraem-se, desse regramento, as seguintes hipóteses:

a) sentença de procedência do pedido: eficácia da sentença e extensão da coisa julgada a todos os titulares de direitos homogêneos; ${ }^{31}$

b) sentença de improcedência do pedido: b.1) limitação da coisa julgada apenas entre as partes, obstando o ajuizamento de novas demandas coletivas, por qualquer outro legitimado; e b.2) todos os membros do grupo, titulares de direitos subjetivos divisíveis, não são atingidos pelo julgamento desfavorável e, por esse motivo, podem, na posição de terceiros, propor ações individuais. ${ }^{32}$

8. Eficácia da sentença de procedência proferida na ação coletiva e extensão da coisa julgada

Reiterando técnica tradicional do processo individual, esse mesmo $\S 3^{\circ}$ do art. 103, autoriza, como efeito da sentença de procedência do pedido formulado na demanda coletiva, a liquidação e a execução pelas vítimas.

Se fosse aplicada a regra clássica do art. 472 do Código de Processo Civil, não haveria como transportar, sem previsão legal expressa, a coisa julgada da ação civil pública às demandas individuais. E isso, não apenas pela evidente diferença de objeto, como ainda porque os efeitos secundários da sentença devem ser contemplados pela lei.

No entanto, inspirando-se no postulado da economia processual, o Código do Consumidor admite o aproveitamento da coisa julgada favorável formada no processo da ação civil pública, possibilitando aos "terceiros beneficiados" e seus sucessores, sem

\footnotetext{
31 Nesse caso, a procedência do pedido aproveita a todos os sujeitos em idêntica posição jurídica e não apenas os membros da associação que ajuizou a ação coletiva. V., nesse sentido, o famoso julgado do TJRJ, $7^{\mathrm{a}}$ CCív., na Apel. n. 2001.001.11462, rel. Des. Marly Macedônio França, atinente ao desabamento do Edifício Palace II, que decidiu: “... Correta a rejeição, pela sentença apelada, da preliminar de ilegitimidade ativa do autor não associado à Associação autora da ação civil pública, cuja sentença ora se liquida. A uma, porque há disposição expressa no art. 103, III, do CDC, no sentido de que o efeito do decisum, in casu, é erga omnes, inexistindo regra que estabeleça limite subjetivo restritivo aos associados da Associação legitimada para a propositura de ações coletivas; e, a duas, porque a sentença liquidanda expressamente dirigiu seus efeitos a todas as vítimas do evento, de forma que a presente questão sequer poderia ser suscitada nesta fase processual...".

32 Para Ada Grinover, esse regime legal teria consagrado a tese de Liebman, porque os terceiros, ausentes do processo, são atingidos pela eficácia natural da sentença de improcedência: Eficácia e autoridade da sentença: a teoria de Liebman no Código de Defesa do Consumidor e no Código Modelo de Processos Coletivos para Ibero-América, Enrico Tullio Liebman oggi - riflessioni sul pensiero di um maestro, p. 105 ss.; O processo - estudos \& pareceres, cap. 16, p. 202 ss.
} 
a exigência de nova sentença condenatória, que procedam à liquidação e à execução da sentença, nos termos dos arts. 97 a 100 do Código de Defesa do Consumidor.

Essa técnica, contudo, não implica ampliação, ope legis, do objeto do processo, para incluir o julgado sobre a obrigação de indenizar. ${ }^{33} \mathrm{Na}$ verdade, trata-se de efeito secundário ou anexo da sentença ditado pela lei, que autoriza a liquidação e a execução individual, pelos respectivos titulares do direito material. A eficácia condenatória é inerente à própria sentença, não havendo qualquer dilatação objetiva da res in iudicium deducta.

9. Eficácia da sentença penal condenatória e extensão da coisa julgada

Igualmente, o art. 103, $\S 4^{\circ}$, do Código de Defesa do Consumidor, aplica aos direitos difusos e coletivos a regra do art. 63 do Código de Processo Penal, e, com isso, confere uma ampliação do conceito de ofendido pelo crime.

A sentença penal condenatória transitada em julgado por crimes contra interesses metaindividuais, previstos, v. g., na legislação consumerista ou ambiental, autoriza a liquidação e subseqüente execução coletiva ou individual em face do condenado, para a respectiva reparação dos danos causados.

Trata-se, como se observa, da mesma técnica que possibilita o transporte in utilibus da coisa julgada penal para as ações individuais de natureza indenizatória.

É possível, por exemplo, que o Ministério Público, diante do trânsito em julgado da sentença penal condenatória por crime ambiental, configurado pela implantação de loteamento clandestino, proponha execução coletiva para o ressarcimento dos danos causados ao meio ambiente. Viabiliza-se, outrossim, o ajuizamento concomitante de execuções individuais pelas pessoas lesadas pelo desmatamento de área contígua. Situações análogas podem ser extraídas, como destaca Ricardo Leonel, das relações de consumo (por ex.: condenação por crime de propaganda enganosa), com a possibilidade de liquidação e execução pelo consumidor lesado (adquirente de produto com características alteradas), e assim em qualquer hipótese de delito perpetrado em detrimento de interesses supra-individuais. ${ }^{34}$

${ }^{33}$ V., em senso contrário, sustentando a ampliação do objeto do processo, GRINOVER, Ada Pelegrini. op. cit., p. 826-827. V., lastreado na mesma opinião, TALAVERA, Glauber Moreno. A coisa julgada no sistema do Código de Defesa do Consumidor. Revista do Instituto dos Advogados de São Paulo, v. 7, n. 14, p. 137-170, jul./dez. 2004, n. 6.7, p. 163.

${ }^{34}$ LEONEL, Ricardo de Barros. Manual do processo coletivo. São Paulo: Revista dos Tribunais, 2002. n. 5.11, p. 281. Confira-se, ainda, GRINOVER, Ada Pelegrini. Código brasileiro de defesa do consumidor comentado pelos autores do anteprojeto. cit., p. 829. 
Duas considerações parecem-me oportunas: $a$ ) a liquidação e a execução devem guardar estreita simetria, objetiva e subjetiva, com a sentença penal, só podendo ser efetivada contra aquele que foi condenado na ação penal. Se empregado de empresa ou servidor público foi condenado por crime ambiental ou contra consumidor, o título executivo judicial (sentença penal condenatória) formou-se apenas em relação a ele, réu na ação penal. Não serão possíveis a liquidação e a execução contra a pessoa jurídica ou contra o Estado, visto que, quanto a estes, não há título executivo, sendo necessária, para tanto, nova ação de conhecimento; e $b$ ) a sentença penal absolutória, quando declarada a inexistência material do fato ou de sua autoria, inviabiliza a tutela individual e coletiva (art. $935 \mathrm{CC}) .{ }^{35}$

10. Limitação subjetiva e territorial da extensão da coisa julgada

Por opção de cunho eminentemente político, a Medida Provisória n. 1.5704, de 22 de julho de 1997, procurou conter a "ameaça" que a tutela coletiva representa ao Estado, reduzindo a eficácia erga omnes, regrada no art. 16 da Lei de Ação Civil Pública, a todos os interessados, mas nos limites da competência territorial do órgão jurisdicional prolator da decisão.

Desprezando-se as inúmeras críticas formuladas pela comunidade jurídica nacional contra essa absurda orientação, foi ela consagrada na Lei n. 9.494/97, que deu nova redação ao referido art. 16: "A sentença civil fará coisa julgada erga omnes, nos limites da competência territorial do órgão prolator, exceto se o pedido for julgado improcedente por insuficiência de provas, hipótese em que qualquer legitimado poderá intentar outra ação com idêntico fundamento, valendo-se de nova prova".

Observou, a propósito, José Marcelo Vigliar, que tal preceito legal representa um verdadeiro retrocesso, porque, a par de seu aspecto marcadamente ideológico, afronta o princípio da isonomia processual e compromete o efetivo acesso à justiça. ${ }^{36}$

\footnotetext{
${ }^{35}$ Cf., nesse sentido, BAZILONI, Nilton Luiz de Freitas. A coisa julgada nas ações coletivas. São Paulo: Juarez de Oliveira, 2004. n. 2.37, p. 147. V., em sentido contrário, GIDI, Antonio. Coisa julgada e litispendência em ações coletivas. São Paulo: Saraiva, 1995. n. 7, p. 177-178; para quem a ação penal pode ter sido mal conduzida ou mal instruída pelo autor, circunstância essa que justificaria a irrelevância da sentença penal absolutória para o processo coletivo; e, com ele, LEONEL, Ricardo de Barros. Manual do processo coletivo. São Paulo: Revista dos Tribunais, 2002. n. 5.11, p. 281.

${ }^{36}$ VIGLIAR, José Marcelo Menezes. Tutela jurisdicional coletiva. São Paulo: Atlas, 1998. n. 2.6.12, p. 182; . A Lei n. 9.494, de 10 de setembro de 1997, e a nova disciplina da coisa julgada nas ações coletivas: inconstitucionalidade. Revista dos Tribunais, São Paulo, n. 745, p. 67-72, nov. 1997. Cf., ainda, SILVA, Bruno Freire e. A ineficácia da tentativa de limitação territorial dos efeitos da coisa julgada na ação civil. In: MAZZEI, Rodrigo; NOLASCO, Rita Dias (Coord.). Processo civil coletivo. São Paulo: Quatier Latin, 2005. n. 3 , p. 337-338.
} 
Não-satisfeito com a mencionada alteração legislativa, em 11 de fevereiro de 1999, o Executivo editou a Medida Provisória, 1.798-137, que introduziu na citada Lei n. 9.494/97 o art. $2^{\circ}$-A. Por força dessa nova regra: "A sentença civil prolatada em ação de caráter coletivo proposta por entidade associativa, na defesa dos interesses e direitos dos seus associados, abrangerá apenas os substituídos que tenham, na data da propositura da ação, domicílio no âmbito da competência territorial do órgão". ${ }^{38}$

Percebe-se, sem dificuldade, que esse preceito incide apenas nas hipóteses de direitos coletivos e individuais homogêneos, visto que, na esfera dos direitos difusos, os respectivos titulares são indeterminados e indetermináveis, ligados por circunstâncias de fato, não havendo como saber o local de seus domicílios.

Ademais, apontando a falta de habilidade do Poder Executivo, esclarece Ada Pellegrini Grinover que o problema, sob o aspecto focado, não diz com a eficácia da sentença, mas, sim, com a amplitude do pedido. E o "âmbito de competência territorial do órgão prolator" é o definido no art. 93, inc. II, do Código de Defesa do Consumidor, tendo o órgão prolator competência nacional ou regional nos expressos termos da lei. ${ }^{39}$

${ }^{37}$ Como destaca Ricardo Leonel, em texto inédito sobre as alterações introduzidas pela EC 45, referida medida provisória foi reeditada, aproximadamente, trintas vezes (em diferentes versões atinentes a outras matérias, mas sem alteração no tópico aqui examinado), com numeração diversa. A última edição foi da MP n. 2.18035, de 24-8-2001, que acabou perenizada no art. $2^{\circ}$ da EC 32, de 11-9-2001, que estabeleceu: "As medidas provisórias editadas em data anterior à da publicação desta emenda continuam em vigor até que medida provisória ulterior as revogue explicitamente ou até deliberação definitiva do Congresso Nacional". Para uma resenha das críticas quanto aos motivos de "política legislativa" e à inconstitucionalidade das medidas provisórias destinadas à restrição da efetividade do processo coletivo, consulte-se LEONEL, Ricardo de Barros. op. cit., p.175-180.

${ }^{38}$ Confira-se, sobre esse ponto, a jurisprudência do STJ: $1^{\mathrm{a}}$ Turma, rel. Min. José Delgado, EDcl. no REsp. n. 640.695-RS: "Impossibilidade de ajuizamento de ação de execução em outros Estados da Federação com base na sentença prolatada pelo Juízo Federal do Paraná nos autos da Ação Civil Pública n. 93.0013933-9 pleiteando a restituição de valores recolhidos a título de empréstimo compulsório cobrado sobre a aquisição de álcool e gasolina no período de jul/87 a out $/ 88$, em razão de que em seu dispositivo se encontra expressa a delimitação territorial adrede mencionada. A abrangência da ação de execução se restringe a pessoas domiciliadas no Estado do Paraná, caso contrário geraria violação do art. $2^{\circ}$-A da Lei n. 9.494/97, litteris: 'A sentença civil prolatada em ação de caráter coletivo proposta por entidade associativa, na defesa dos interesses e direitos dos seus associados, abrangerá apenas os substituídos que tenham, na data da propositura da ação, domicílio no âmbito da competência territorial do órgão prolator"”; $1^{\text {a }}$ Turma, rel. Min. Teori Zavascki, REsp. n. 625.996-SC: "Nos termos do art. 566 do CPC, tem legitimidade para 'promover a execução forçada', além do Ministério Público, nos casos prescritos em lei, 'o credor a quem a lei confere título executivo'. Na hipótese dos autos, o comando sentencial da ação civil pública restringiu sua eficácia subjetiva aos contribuintes domiciliados no Estado do Paraná, sendo inviável, sob pena de ofensa ao princípio da coisa julgada, a sua extensão a contribuintes domiciliados em Santa Catarina, como é o caso dos Autores, que não possuem, portanto, título executivo". V., ainda, ZAVASCKI, Teori Albino. Processo coletivo. São Paulo: Revista dos Tribunais, 1998. p. 190.

${ }^{39}$ GRINOVER, Ada Pelegrini. Código brasileiro de defesa do consumidor comentado pelos autores do anteprojeto. cit., p. 822. Cf., também, VIGLIAR, José Marcelo Menezes. Ação civil pública. 3. ed. São Paulo: Atlas, 1999. n. 10.1, p. 112-113. 
11. Código-Modelo de Processos Coletivos para Ibero-América

Aprovado nas Jornadas Ibero-Americanas, realizadas em Caracas, em outubro de 2004, o Código-Modelo de Processos Coletivos para Ibero-América, no que toca ao instituto da coisa julgada, seguiu parcialmente a sistemática da lei brasileira em matéria de direitos transindividuais, em particular, o regime do art. 103 do Código de Defesa do Consumidor, mas, ainda, trouxe importante inovação.

Preceitua o art. 33 do referido diploma legal que: "Nas ações coletivas de que trata este código, a sentença fará coisa julgada erga omnes, exceto se o pedido for julgado improcedente por insuficiência de provas, hipótese em que qualquer legitimado poderá intentar outra ação, com idêntico fundamento, valendo-se de nova prova. $\S 1^{\circ}$ Mesmo na hipótese de improcedência fundada nas provas produzidas, qualquer legitimado poderá intentar outra ação, com idêntico fundamento, no prazo de 2 (dois) anos contados da descoberta de prova nova, superveniente, que não poderia ter sido produzida no processo, desde que idônea, por si só, para mudar seu resultado. $\S 2^{\circ}$ Tratando-se de interesses ou direitos individuais homogêneos, em caso de improcedência do pedido, os interessados poderão propor ação de indenização a título individual. $\S 3^{\circ}$ Os efeitos da coisa julgada nas ações em defesa de interesses ou direitos difusos ou coletivos não prejudicarão as ações de indenização por danos pessoalmente sofridos, propostas individualmente ou na forma prevista neste código, mas, se procedente o pedido, beneficiarão as vítimas e seus sucessores, que poderão proceder à liquidação e à execução, nos termos dos arts. 22 a 24. $\S 4^{\circ}$. Aplica-se o disposto no parágrafo anterior à sentença penal condenatória. $\S 5^{\circ} \mathrm{A}$ competência territorial do órgão julgador não representará limitação para a coisa julgada erga omnes".

Com redação mais aperfeiçoada daquela que lhe serviu de modelo, tal dispositivo legal contém, em apertado resumo, as seguintes regras:

a) sentença de procedência do pedido: eficácia da sentença e extensão da coisa julgada erga omnes, não sujeita a qualquer limitação territorial;

b) sentença de improcedência: impede o ajuizamento de nova demanda por qualquer outro legitimado;

c) sentença de improcedência do pedido por insuficiência de provas: não impede o ajuizamento da mesma demanda, por qualquer legitimado, fundado em prova nova;

d) sentença de improcedência fundada nas provas produzidas: não impede o ajuizamento da mesma demanda, por qualquer legitimado, no prazo de 2 anos, a contar da 
descoberta de prova superveniente, impossível de ter sido produzida no primeiro processo e idônea a mudar o seu resultado;

e) sentença de procedência no caso de direitos individuais homogêneos: extensão da coisa julgada a todos os interessados, que poderão inclusive liquidar e executar o julgado;

f) sentença de improcedência no caso de direitos individuais homogêneos: não impede o ajuizamento de demandas individuais; e

g) sentença penal condenatória: passível de liquidação e execução, na esfera civil, pelas vítimas ou sucessores (art. 475-N, II, CPC).

Acrescente-se que toda essa orientação legislativa também prevalece na hipótese de ação coletiva passiva (defendant class action), contemplada no art. 35 do Código-Modelo: “Ações contra o grupo, categoria ou classe - Qualquer espécie de ação pode ser proposta contra uma coletividade organizada ou que tenha representante adequado, nos termos do parágrafo $2^{\circ}$ do art. $2^{\circ}$ deste código, e desde que o bem jurídico a ser tutelado seja transindividual (art. $1^{\circ}$ ) e se revista de interesse social". ${ }^{40}$

A “coisa julgada passiva", na dicção dos arts. 36 e 37, recebe duplo tratamento, dependendo do objeto da ação coletiva.

Se a demanda versar sobre direito difuso, a extensão da coisa julgada é erga omnes, "vinculando os membros do grupo, categoria ou classe" (art. 36).

Tratando-se, por outro lado, de direito individual homogêneo, a coisa julgada também se estende a todos, no plano coletivo, mas a sentença de procedência não vinculará os membros do grupo, categoria ou classe, que poderão mover ações próprias ou defender-se na execução do julgado, para afastar a eficácia da sentença na sua esfera individual (art. 37).

O Código-Modelo, como se verifica, traçou importante distinção, na ação coletiva passiva, quanto à vinculação dos sujeitos interessados, a partir da divisibilidade ou não do bem jurídico tutelado. Sendo indivisível, a extensão da coisa julgada abrange todos os membros do grupo, categoria ou classe. Entretanto, se for divisível, a coisa julgada não vincula os integrantes do grupo, categoria ou classe, que poderão ajuizar ações próprias para afastar a eficácia da sentença em sua esfera jurídica individual. ${ }^{41}$

\footnotetext{
${ }^{40}$ V., sobre as denominadas defendant class actions no direito brasileiro, DINAMARCO, Pedro da Silva. Ação civil pública. São Paulo: Saraiva, 2001. n. 15.1, p. 268 ss..

${ }^{41}$ V., a respeito, MENDES, Aluísio Gonçalves de Castro. Código Modelo de Processos Coletivos. In: LUCON, Paulo Henrique do Santos. (Coord.). Tutela coletiva: 20 anos da lei de ação civil pública e do fundo de defesa de direitos difusos : 15 anos do código de defesa do consumidor. São Paulo: Atlas, 2006. n. 11, p. 45-46.
} 
Todavia, se a ação coletiva, nesse caso, for ajuizada contra o sindicato, como substituto processual da categoria, a extensão da coisa julgada abrange todos, tornando imutável a decisão para os seus membros, mesmo na hipótese de procedência do pedido (art. 37, par. ún.).

\section{Anteprojeto do Código Brasileiro de Processos Coletivos}

Idêntica sistemática da coisa julgada, regrada no Código Modelo de Processos Coletivos para os países ibero-americanos, estava contemplada nas primeiras versões do Anteprojeto do Código Brasileiro de Processos Coletivos.

Contudo, é de se salientar que na derradeira proposta formulada, apresentada pelos seus idealizadores em dezembro de 2005, foram introduzidas algumas alterações na redação, aperfeiçoando ainda mais, no art. 12, o regime da coisa julgada no âmbito da tutela coletiva.

A única modificação substancial digna de destaque é aquela constante do $\S$ $6^{\circ}$ do art. 12, que autoriza o réu, de processo coletivo cujo pedido foi julgado procedente, a mover ação, no prazo de dois anos, "contados da descoberta de prova nova, superveniente, que não poderia ter sido produzida no processo, desde que idônea, por si só, para mudar seu resultado".

São Paulo, agosto de 2007.

\section{Referências}

ALVIM, Eduardo Arruda. Apontamentos sobre o processo das ações coletivas. In: MAZZEI, Rodrigo; NOLASCO, Rita Dias. (Coords.). Processo civil coletivo. São Paulo: Quartier Latin, 2005.

ARAÚJO FILHO, Luiz Paulo da Silva. Ações coletivas: a tutela jurisdicional dos direitos individuais homogêneos. São Paulo: Forense, 2000.

BAZILONI, Nilton Luiz de Freitas. A coisa julgada nas ações coletivas. São Paulo: Juarez de Oliveira, 2004.

BEDAQUE, José Roberto dos Santos. Poderes instrutórios do juiz. 3. ed. São Paulo: Revista dos Tribunais, 2001. 
CAPPELLETTI, Mauro. Appunti sulla tutela giurisdizionale di interessi collettivi o diffusi. In: Le Azioni a tutela di interessi collettivi: atti del Convegno di studio (Pavia, 11-12 giugno 1974). Padova: Cedam, 1976.

. Formazioni socialli e interessi di gruppo davanti alla giustizia civile. Rivista di Diritto Processuale, Padova, v. 30, n. 3, p. 361-402, 1975.

CARPI, Federico. Cenni sulla tutela degli interessi collettivi nel processo civile e cosa giudicata. Rivista Trimestrale di Diritto e Procedura Civile, 1974.

COMOGLIO, Luigi Paolo. Il principio di economia processuale. Padova: Cedam, 1982. v. 2.

DINAMARCO, Pedro da Silva. Ação civil pública. São Paulo: Saraiva, 2001.

FISCH, William B. European analogues to the class action: group action in france and germany. The American Journal of Comparative Law, Berkeley, v. 27, n. 1, p. 51-79, winter, 1979.

FRIEDMAN, David. More Justice for Less Money. The Journal of Law and Economics, Chicago, v. 39, n. 1, p. 211-240, apr. 1996.

GIDI, Antonio. Coisa julgada e litispendência em ações coletivas. São Paulo: Saraiva, 1995.

GIUSSANI, Andréa. Studi sulle “class actions”. Padova: Cedam, 1996.

GRECO FILHO, Vicente. Comentários ao Código de Proteção do Consumidor. São Paulo: Saraiva, 1991.

GRINOVER, Ada Pellegrini. Código brasileiro de defesa do consumidor comentado pelos autores do anteprojeto. 6. ed. Rio de Janeiro: Forense Universitária, 1999.

. Eficácia e autoridade da sentença: a teoria de Liebman no Código de Defesa do Consumidor e no Código Modelo de Processos Coletivos para Ibero-América, Enrico Tullio Liebman oggi riflessioni sul pensiero di um maestro. Milano: Giuffrè, 2004

As garantias constitucionais do processo nas ações coletivas. Revista de Processo, São Paulo, v. 11, n. 43, p. 19-30. jul./set. 1986.

. O processo: estudos e pareceres. São Paulo: DPJ, 2006.

GUERRA FILHO, Willis Santiago. Eficácia ultra-subjetiva da coisa julgada e garantia do contraditório em ações coletivas. In: MAZZEI, Rodrigo; NOLASCO, Rita Dias. (Coords.). Processo civil coletivo. São Paulo: Quartier Latin, 2005. 
HORNSTEIN, George D. Legal Therapeutics: the "Salvage" Factor in Counsel Fee Awards. Harvard Law Review, Cambridge, v. 69, n. 4, p. 658-682, feb. 1956.

LEAL, Márcio Flávio Mafra. Ações coletivas: história, teoria e prática. Porto Alegre: Sérgio Fabris, 1998.

LEONEL, Ricardo de Barros. Manual do processo coletivo. São Paulo: Revista dos Tribunais, 2002.

LUCON, Paulo Henrique dos Santos; GABBAY, Daniela. Coisa julgada secundum eventum probationis e pedido nas ações coletivas. São Paulo, 2006. (no prelo)

MANCUSO, Rodolfo. Ação popular. São Paulo: Revista dos Tribunais, 1993.

MAZZILLI, Hugo Nigro. Notas sobre a mitigação da coisa julgada no processo coletivo. In: MAZZEI, Rodrigo; NOLASCO, Rita Dias. (Coords.). Processo civil coletivo. São Paulo: Quartier Latin, 2005.

MENDES, Aluísio Gonçalves de Castro. Código modelo de processos coletivos. In: LUCON, Paulo Henrique dos Santos. Tutela coletiva. São Paulo: Atlas, 2006.

MESQUITA, José Ignácio Botelho de. A coisa julgada no Código do Consumidor. Rio de Janeiro: Forense, 2004.

. A coisa julgada no Código do Consumidor. Revista Forense, Rio de Janeiro, v. 90, n. 326, p. 79-84, abr./jun. 1994.

. Na ação do consumidor, pode ser inútil a defesa do fornecedor. Revista do Advogado, São Paulo, n. 33, p. 802, dez. 1990.

MICKLITZ, Hans W. La loi allemande relative au regime juridique des conditions générales des contrats du 9.12.76 - bilan de onze annés d'application. Revue Internationale du Droit Comparé, Paris, v. 41, n. 1, p. 101-122, 1989.

MOREIRA, José Carlos Barbosa.Os poderes do juiz na direção e na insrução do processo. In:

Temas de direito processual. 4. série. São Paulo: Saraiva, 1989.

MORELLO, Augusto M. Aspectos evidentes de la realidad: la reforma de la justicia. La Plata: LEP, 1998.

PINHO, Humberto Dalla Bernardina de. A natureza jurídica do direito individual homogêneo e sua tutela pelo Ministério Público como forma de acesso à Justiça. Rio de Janeiro: Forense, 2002. 
PROTO PISANI, Andrea. Note in tema di limiti soggettivi della sentenza civile. Foro Italiano, 1985.

RAPIARDA, Cristina. Spunti in tema di efficacia del giudicato secundum eventum litis con particulare riguardo all'esperienza della legge tedesca sulle condizioni generali di contratto. In: Studi in onore di Enrico Allorio. Milano: Giuffrè, 1989. v. 1.

ROMY, Isabelle. Litiges de masse. Des class actions aux solutions suisses dans les cas de pollutions et de toxiques. Fribourg: Éditions Universitaires, 1997.

ROTH, Günter H. La nouvelle loi allemande sur les conditions générales du contrat (AGB-Gesetz) du 6.12.1976. Revue Internationale du Droit Comparé, Paris, 1977.

SILVA, Bruno Freire e. A ineficácia da tentativa de limitação territorial dos efeitos da coisa julgada na ação civil. In: MAZZEI, Rodrigo; NOLASCO, Rita Dias. (Coords.). Processo civil coletivo. São Paulo: Quartier Latin, 2005.

STIGLITZ, Gabriel A. Protección jurídica del consumidor. 2. ed. Buenos Aires: Depalma, 1990.

TALAVERA, Glauber Moreno. A coisa julgada no sistema do Código de Defesa do Consumidor. Revista do Instituto dos Advogados de São Paulo, São Paulo, v. 7, n. 14, p. 137-170, jul./dez. 2004.

TROCKER, Nicolò. I limiti soggettivi del giudicato tra tecniche di tutela sostanziale e garanzie di difesa processuale. Rivista di Diritto Processuale, Padova, v. 43, p. 34-95, 1988.

TUCCI, José Rogério Cruz e. Técnica processual civil no Código de Defesa do Consumidor: devido processo legal e tutela jurisdicional. São Paulo: Revista dos Tribunais, 1993.

VENTURI, Elton. Sobre a intervenção individual nas ações coletivas. In: DIDIER JÚNIOR, Fredie; WAMBIER, Teresa Arruda Alvim; BRONZATTO, Alexandre Novelli (Coords.) Aspectos polêmicos e atuais sobre os terceiros no processo civil e assuntos afins. São Paulo: Revista dos Tribunais, 2004.

VIGLIAR, José Marcelo Menezes. Ação civil pública. 3. ed. São Paulo: Atlas, 1999.

VIGLIAR, José Marcelo Menezes. A Lei n. 9.494, de 10 de setembro de 1997, e a nova disciplina da coisa julgada nas ações coletivas: inconstitucionalidade. Revista dos Tribunais, São Paulo, n. 745, p. 67-72, nov. 1998.

VIGLIAR, José Marcelo Menezes. Tutela jurisdicional coletiva. São Paulo: Atlas, 1998. ZAVASCKI, Teori Albino. Processo coletivo: tutela de direitos coletivos e tutela coletiva de direitos. São Paulo: Revista dos Tribunais, 2006. 